\title{
Application of Contextual Teaching and Learning (CTL) Components In Telecommunication Network Design and Optimization Course
}

\author{
Firdaus $^{a, *}$, Fatma Dewi ${ }^{\mathrm{b}}$

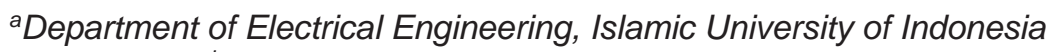 \\ ${ }^{b}$ Madrasah Aliyah Negeri (MAN) 3 Cilacap \\ *Corresponding author: firdaus@uii.ac.id
}

\begin{abstract}
One of the academic problems in the Electrical Engineering Undergraduate Program of Islamic University of Indonesia is the thesis work beyond the target time, so the average period of study became over time. Several solutions have been worked out, but the results have not been significant impact. The biggest problem is the lack of research experience and support skills in research. This research proposes a new solution by inviting students to do integrated learning and research in the Telecommunication Network Design and Optimization course. The selected learning model is Contextual Teaching and Learning based on Problem Based Learning. CTL is a teaching-learning strategy that emphasizes the full process of student involvement in order to discover the material learned and relate it to real life situations that encourage students to apply it in their lives. The results can improve the students achievement of competencies and give direct experience to students to conduct the research. This is evidenced by the increase of the average mark from 63.78 to 78.91 and the availability of student to write the good research reports.
\end{abstract}

Keywords: contextual, problem based learning, integrated learning and research, study period

\section{INTRODUCTION}

Department of Electrical Engineering, Islamic University of Indonesia was established in 1997 and now has received accreditation A from National Accreditation Board. One of the problems that need completion is the study period of the student which is still beyond the specified time. Based on the data of graduates from September 2011 to August 2015, the average study period of students is 6.03 years. Included in it there are 11 students whose study period between 10-13 years. The curriculum is designed for 8 semesters or 4 years. When viewed from the time required to finish the courses, most students take 6-8 semesters. So one of the main problems is the over time of thesis process.

Several solutions have been taken, including opening the Research Methods course in each semester and require students to make research proposals in the course. Then in each semester, a thesis seminar is held, where the lecturers offer research titles for student. However, these efforts have not made significant improvements. Apparently the biggest problem is the lack of research experience and lack of support skills in research such as programming.

The new solution proposed through this research is to provide direct research experience to students and equip students with the necessary support capabilities that are integrated in a course. Appropriate course is the final level of courses. For telecommunication concentration, one of its top courses is Telecommunication Network Design and Optimization which is held in $7^{\text {th }}$ semester.

Since the main purpose is to provide a direct learning experience to the students and relate it to the facts in the field, one of the most appropriate learning methods is the Contextual Teaching and Learning (CTL) method. This study will discuss how to apply the components of Contextual Teaching and Learning method (CTL) in the Telecommunication Network Design and Optimization Course based on Problem Based Learning approach (PBL) to improve the achievement of competency and provide direct experience to the students to conduct research. 


\section{LITERATURE REVIEW}

Some experts put forward the definition of CTL learning methods. According to Sanjaya, CTL is a teaching-learning strategy that emphasizes the full process of student involvement in order to find the material learned and relate it to real life situations that encourage students to apply it in their lives. [1]

There are three things that must be understoodin the concept of CTL. First, CTL emphasizes the process of involvement of students to find material and meaning, so that the learning process is oriented directly to the experience process. The learning process in the context of CTL does not expect students to receive course material only, but the process of searching and finding their own knowledge.

Secondly, CTL encourages students to discover the relationship between the material learned and the real life situation, it means that students are required to capture the relationship between the learning experience and real life. This is very important, because by being able to correlate the material found with real life, the material will be meaningful functionally and it will be embedded in the student's memory, so it will not be easily forgotten.

Third, CTL encourages students to apply it in life, it means that CTL not only expects students to understand the material that they are learning, but how the subject matter can color their behavior in everyday life. Lesson material in the context of CTL is not to be stacked in the brain and then forgotten, but as their provision in real life.

The process of contextual learning involves relating, experiencing, applying, cooperating, and transferring [2]. The use of CTL in learning has been shown to improve the effectiveness of learning $[3,4]$.

While Johnson [5] mentions that CTL is a system that stimulates the brain to construct patterns that embody meaning. CTL is a teaching system that matches the brain that produces meaning by linking the academic content to the context of the student's daily life. Johnson also revealed that to help develop student potential, CTL provides an opportunity to use higher-order thinking skills in the real world. Then students will gradually awaken the habit of thinking well, open-minded, listening to others sincerely, thinking before acting, underlying conclusions with strong evidence, and training the imagination.

The CTL system consists of eight components [5], which make meaningful connections, perform meaningful deeds, conduct self-directed learning, cooperate, think critically and creatively, help individuals to grow and develop, achieve high standards, and using authentic scoring. The details are as follows:

1. Be a self-regulated and active student, so as to develop individual interests, as well as cooperate individually and in groups, learn by practice.

2. Building the linkages between campus and real-life contexts such as business and community institutions.

3. Doing meaningful work i.e. work that has a purpose, useful to others, which involves the process of making choices, and producing tangible and unreal products.

4. Use high-level thinking that is creative and critical i.e. analyzing. Synthesize, solve problems, makes decisions, use logic and evidence.

5. Working together, which brings students to work effectively in groups, helps them understand that what they do affects others, helps them communicate with others.

6. Develop each individual that is giving attention, putting high expectations for every student. Encourage and motivate students. Students cannot succeed without the support of more mature people and Students respect their peers.

7. Recognize and achieve high standards of identifying clear goals and motivating students to achieve them.

According to Nurhadi [6], learning with CTL approach involves seven main components of effective learning, namely constructivism, questioning, inquiry, learning community, modeling, reflection, and authentic assessment. Here is an explanation of the seven main components of effective learning in relation to CTL learning.

1. Constructivism

Constructivism is the process of building or composing new knowledge in the cognitive structure of students based on experience. According to the philosophy of constructivism, knowledge is formed not only of the objects alone, but also of the individual's ability as subject to capture every object he observes. That assumption then underlies CTL. Learning through CTL basically encourages students to construct their knowledge through observation process and experience. When the student experience allows them 
to find meaning in academic lessons, these lessons forms the neural pathways in the student's brain. Then the brain keeps the lesson.

2. Questioning

A person's knowledge always starts from asking. Principles that must be considered in the learning related to the askingcomponent, among others, extracting information and confirmation of what has been known more effective when done through asking. In CTL, lecturers do not convey information just like that, but fishing so that students can find their own. Therefore, the questioning role is very important, because through the questions lecturers can guide and direct the students to find every material he learned.

3. Inquiry

Inquiry means the learning process is based on search and discovery through the process of thinking systematically. The knowledge and skills acquired by students are expected not the result of remembering a set of facts, but the result of finding themselves. Thus in the planning process, the lecturer is not preparing a number of materials to memorize, but designing the learning that allows the student to find the material himself that must be understood.

4. Learning Community

A problem cannot be solved alone, but requires the help of others. So the concept of learning community suggested that the learning outcomes obtained from cooperation with others. Learning outcomes are obtained from sharing among friends, between groups, and between people who know and do not know either in the classroom or outside the classroom.

5. Modeling

This component suggests that certain skills or knowledge learning uses models that students can imitate. In CTL learning, modeling can be the use of examples, such as how to operate something, show the work, or show an appearance. A lecturer can act as a model, for example when demonstrating something to his students, but lecturers are not the only model that can be played in CTL classes.

6. Reflection

Reflection is the most important component of any learning, by thinking back about what has been done in the past. In learning with the CTL approach, at the end of each lesson, the lecturer gives students the opportunity to "reflect" or recall what they have learned. The lecturer allows the student freely to interpret his own experience, so he can conclude about his learning experience.

7. Authentic Assessment

Authentic assessment is the process by which lecturers collect information about student learning progress. Authentic assessment in CTL learning is directed at the process of observing, analyzing, and interpreting the data that has accumulated in the learning process, not merely the learning outcomes. Assessment data collected must be obtained from the actual activities undertaken by students during the learning process so that the assessment data obtained is called authentic data. In the authentic assessment, the lecturer assesses the knowledge and skills acquired by the students. Assessment can be done not only by lecturers, but can be done by other friends or others.

Based on the definition and components of CTL, as well as the results that have been obtained by using this techniques, then the use of this method is in accordance with the main objectives of this research. The objective is to give students direct experience of learning and research process based on problems that have been formulated.

\section{METHOD}

The steps taken to apply the components of CTL system in the learning process of Telecommunication Network Design and Optimization course are as follows:

The first step is to identify the components of CTL that will be applied in the learning process by conducting literature study. The second step is to describe the components in activities that can be implemented in the learning process. The third step is to design a Learning Activity Unit (SAP) based on activities designed and tailored to Syllabus and Course Outline.

Based on literature study, there are eight components of CTL system [5], namely:

1. Make meaningful connections

2. Perform meaningful deeds

3. Conduct self-regulated learning

4. Cooperate 
5. Think critically and creatively

6. Assist individuals to grow and develop

7. Achieve high standards

8. Use authentic assessment

The next step is to describe the components in activities that can be implemented in the learning process. Detailed implementation of the eight components of CTL system in the learning process of Telecommunication Network Design and Optimization course can be seen in Table 1. and Table 2.

TABLE 1. Detailed implementation of CTL system components

\begin{tabular}{ll}
\hline \multicolumn{1}{c}{ CTL System Components } & \multicolumn{1}{c}{ Application } \\
\hline Make meaningful connections & Look for linkages between courses taken (Digital \\
& Communication, Traffic Engineering, Mobile Communications \\
& Systems, Information Theory and Encoding) with this course. \\
\hline Perform meaningful deeds & $\begin{array}{l}\text { Performing design and performance test of } \\
\text { telecommunication network using real data in field. }\end{array}$ \\
\hline Conduct self-regulated learning & $\begin{array}{l}\text { In some lecture meetings, general issues will be discussed, } \\
\text { then students in groups will proceed on their own, and the } \\
\text { results will be presented at the next meeting. }\end{array}$ \\
\hline Cooperate & $\begin{array}{l}\text { The subject tasks that become the largest component of } \\
\text { determinants of value will be done in groups of } 3 \text { to } 4\end{array}$ \\
\hline Think critically and creatively & students. \\
\hline Assist individuals to grow and develop & $\begin{array}{l}\text { Each student will provide input and questions to other } \\
\text { participants in the discussion and presentation series. }\end{array}$ \\
& $\begin{array}{l}\text { The results of the work will be routinely monitored and given } \\
\text { inputs to better the results of his work. }\end{array}$ \\
\hline Achieve high standards & $\begin{array}{l}\text { Participants in accordance with their respective groups are } \\
\text { required to write reports that are made similar to thesis }\end{array}$ \\
& reports. \\
\hline Use authentic assessment & The assessment portion is set as follows: \\
& Mid Test: 15\% \\
& Final Exam: $15 \%$ \\
Subject Tasks: $70 \%$ \\
(Task value derived from report \& presentation values)
\end{tabular}

TABLE 2. The design of CTL activities and steps

\begin{tabular}{cll}
\hline No & \multicolumn{1}{c}{ Activities } & \multicolumn{1}{c}{ CTL learning steps } \\
\hline 1 & - Learning Contract & - Contract study (15 minutes) \\
& - Explanation of Learning Methods & - Explanation of learning method (15 minutes) \\
- Overview of some courses taken & - The students are divided into groups (@ 3 \\
(Digital Communications, Traffic & persons), discussing the link between the \\
Engineering, Mobile Communications & previous course and this course. (60 minutes) \\
Systems, Information Theory and & - Presentation of each group and discussion (60 \\
Encoding) and discussion of the & minutes) \\
course's relevance in this course. & \\
- Division of Groups & - Introduction (30 minutes) \\
- Division of Design Duties & - Discussion of groups related to the ways and \\
- Discuss the ways and stages in the & stages in telecommunication network design (45 \\
design & minutes) \\
& - Presentations and class discussions about the \\
& - Steps in network design (45 minutes) \\
& - Delivery assignments and explanations (30 \\
& - Problem for task: Design of 4G LTE Network in \\
& Sleman (Group 1), Kulon Progo (Group 2), and
\end{tabular}


3 Preparation of research proposals based on the division of tasks (Chapter 1 Thesis)

4 Presentation and discussion of research proposals (Chapter 1 Thesis)

5 Discussion of Literature Review (Chapter 2 Thesis)

Presentation of relevant research results that already exist

6 Discussion of Stages and Methods of Design (Chapter 3 Thesis)

7 Training on the use of supporting tools (software)

8 Training on the use of supporting tools (software)

9 Development discussion and presentation (Chapter 4 Thesis)

10 Development discussion and presentation (Chapter 4 Thesis)

11 Development discussion and presentation (Chapter 5 Thesis)

12 Discussion of telecommunication network optimization techniques

13 Field data collection and report preparation

\section{Presentation of optimization results}

Bantul (Group 3)

- Introduction (30 minutes)

- Discussion group and write chapter 1, covering background, objectives, problem formulation, problem limitation (90 minutes)

- Evaluation and feedback for each group (30 minutes)

- Introduction (15 minutes)

- Presentation by each group (@15 minutes) followed by discussion forum @ 15 minutes)

- Details explanation for references related to each title (one group of at least 3 papers)

- Introduction (15 minutes)

- Presentation by each group (@30 minutes) continued with discussion forum @ 10 minutes)

- Quiz related to the presentation material (15 minutes)

- Introduction (15 minutes)

- Discussion of one class, related steps in the design (30 minutes)

- Discussion of the group, detailing the design steps according to each topic (60 minutes)

- Presentation of each group (@15 minutes)

- Introduction and installation (30 minutes)

- Introduction of software and its basic functions (120 minutes)

- Step by step design using software (120 minutes)

- Quiz (30 minutes)

- Task (use software according to the topic of each design)

- Introduction (15 minutes)

- Discussion group (105 minutes)

- The class discussion (30 minutes)

- Introduction (15 minutes)

- Discussion group (105 minutes)

- The class discussion (30 minutes)

- Presentation (@20 minutes), continued discussion (@30 minutes)

- Introduction (15 minutes)

- Discussion class (90 minutes)

- Explanation of tool usage (45 minutes)

- Prepare the device (15 minutes)

- Field data retrieval (120 minutes)

- Assignment: creates report (15 minutes)

- Presentation (@20 minutes), continued discussion (@30 minutes)

\section{Role of PBL in Learning with CTL Approach}

A meaningful learning through CTL would be better if it had a clear conceptual learning procedure or framework. The conceptual framework of learning illustrates a systematic procedure in organizing learning experiences to achieve specific learning goals, known as the Learning Model. In order for the learning process to be directed, the PBL is a learning model that can increase student activity. This learning model serves as a guide for the designer of learning in planning and carrying out learning activities, so that learning activities really is a purposeful activity that is arranged systematically. 
Problem-based learning is a model that emphasizes teaching staff issues problems, questions, and facilitates inquiry and dialogue. This model is also known as Problem Based Instruction (PBI), with its main features include:

1. Submission of questions or problems

2. Focus on interdisciplinary linkages

3. Authentic inquiry

4. Produce the product

5. Cooperation.

PBL is primarily developed to help students develop thinking skills, problem solving and intellectual skills, learn various roles of adults through their involvement in real-life experiences or simulations; and become an autonomous and independent learner. The learning environment and management system of $\mathrm{PBL}$ is characterized by an open, democratic process and active student role.

\section{Synchronization between Syllabus and Method}

The implementation of the proposed learning method has the same time allocation as the previous teaching method. While in the new teaching method, much time is spent on discussion, it is necessary to be designed so that the material in the syllabus can be delivered well to the students. The material in Syllabus is:

1. $3 G$ technology (WCDMA)

2. Design of $3 G$ Network

3. $3 G$ Network Optimization

4. 4G Technology

5. Design of $4 \mathrm{G}$ Network

6. 4G Network Optimization

The material of $3 G$ and $4 G$ technologies are discussed at first and second meeting. The design material of $3 G$ and $4 G$ networks is discussed at the third meeting until the eleventh. Then the content of $3 G$ and $4 \mathrm{G}$ network optimization is discussed at the twelfth until the fourteenth meeting.

There are two standards of $4 G$ network, namely Wimax and LTE. In practice in Indonesia, Wimax technology first appeared and initially the government set up Indonesia to adopt Wimax standards. This is evidenced by the government's first regulation and leasing frequency for Wimax services. But on the other hand, operators prefer to use LTE technology standards. This is because it is easier and cheaper to upgrade 3G-WCDMA network to LTE network than Wimax.

Long Term Evolution or also called LTE is a standard high-speed wireless data communication technology for mobile communication based on the development of GSM / EDGE and UMTS / HSPA technologies. The technology was officially developed by 3GPP which also issued standards and specifications for UMTS and GSM. LTE is present to answer high-speed data communication problems that can no longer be served by previous technologies such as HSPA and so on.

LTE is specifically discussed by 3GPP through a release known as R8 or release 8 in conjunction with the standard for SAE (System Architecture Evolution). According to ITU-T specification [4] a technology that can be accepted as fourth generation communication technology is able to fulfill a requirement as follows:

1. Peak Downlink $(\mathrm{DL})$ rate $>100 \mathrm{Mbps}$ for high mobility applications and > 1000 Mbps for fixed applications.

2. Peak Uplink (UL) rate $>50$ Mbps.

3. Low User Plane Latency $\leq 5 \mathrm{~ms}$.

4. Internet-oriented Protocol (IP) Network Packet Switch (PS).

5. Seamless Mobility / Unlimited Mobility (uninterrupted).

6. Flexible allocation of radio channel bandwidth in the range of $1.4 \mathrm{MHz}$ up to $20 \mathrm{MHz}$ with optimum up to $40 \mathrm{MHz}$.

\section{The Use of Software}

This study uses a tool (software) as one of the learning media. To overcome the less optimal of learning media, educators are required to be able to empower educational facilities and infrastructure available as much as possible. Satya Adi [7] expressed his opinion that the lecturer as one of the educators is obliged to straighten the learning objectives by utilizing auxiliary media, so that will regenerate the real learning 
motivation in the learners. Learning media are all sources either in the form of tools or any equipment that if used by lecturers and learners in the process of learning to teach will be able to improve the ability of learners and acceleration/ accelerate understanding of learners.

The use of this software is expected to increase the level success of learning, previously it has also been proven that learning CTL by using laboratory approach is better than CTL learning with assignment approach [8]. Software used in this lecture is Atoll, software atoll is a software commonly used by mobile network operators to perform planning and optimization of cellular networks. In addition to Atoll can also actually use other network simulation software, such as Opnet and NS (Network Simulator). But because LTE includes the latest technological standards, make sure the software series used support LTE.

Picture of the learning atmosphere can be seen in Figure 1. (outdoor activities) and Figure 2. (indoor activities).

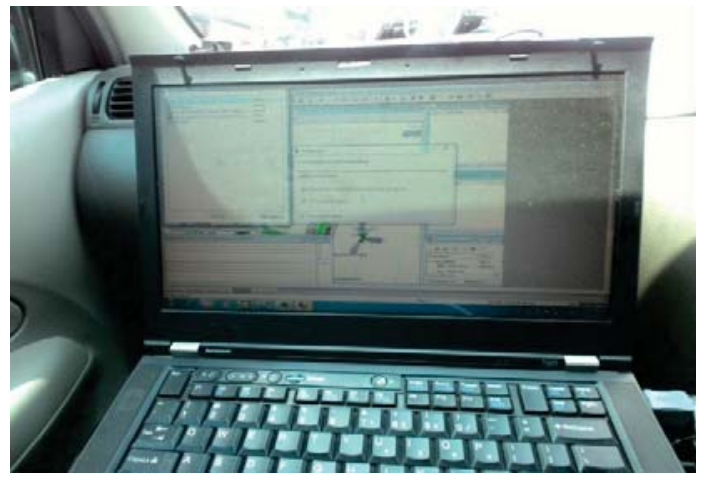

FIGURE 1. The drive test activity

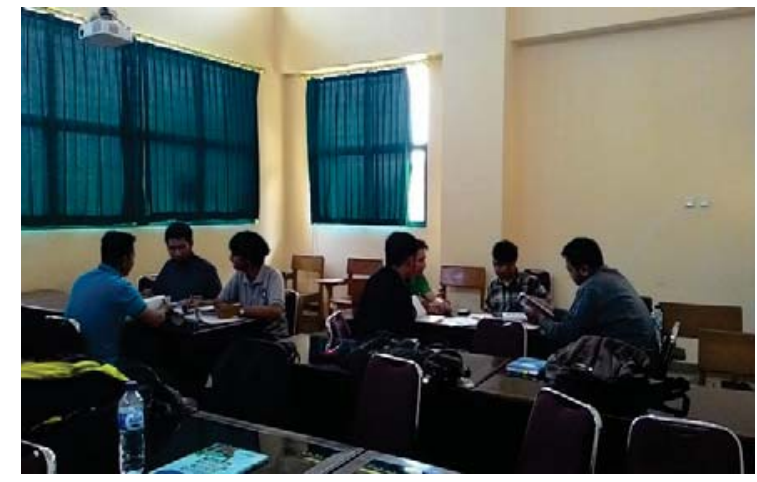

FIGURE 2. Classroom discussion activities

\section{RESULTS AND DISCUSSION}

In this section will be discussed the results of evaluation of learning, student responses, lesson learning, and sustainability.

\section{Learning Evaluation Results}

The results of this study can be seen from the evaluation conducted, the evaluation is done in two forms. First is a written exam, and the second is to prepare a research report and present it. Target competencies and written exam questions can be seen in Table 3.

TABLE 3. Competencies and exam questions

\begin{tabular}{|c|c|c|}
\hline & Target Competencies & Written Exam (Mid and Final Exam Semester) \\
\hline 1. & $\begin{array}{l}\text { Understand 3G network } \\
\text { architecture }\end{array}$ & - Explain step by step RF Planning process \\
\hline 2. & $\begin{array}{l}\text { Designing a } 3 G \text { network } \\
\text { radio section }\end{array}$ & - Perform Scrambling Code planning on the $3 G$ network \\
\hline 3. & $\begin{array}{l}\text { Understand the } 4 \mathrm{G}-\mathrm{LTE} \\
\text { network architecture }\end{array}$ & $\begin{array}{l}\text { - What distinguishes LTE from } 3 G \text { ? } \\
\text { - Describe the LTE network topology } \\
\text { - Describe the } 4 \text { major supporting components of LTE technology }\end{array}$ \\
\hline 4. & $\begin{array}{l}\text { Designing } 4 G-L T E \text { radio } \\
\text { network }\end{array}$ & $\begin{array}{l}\text { - Write briefly the review of the LTE network designing libraries you } \\
\text { created earlier } \\
\text { - What should be considered in calculating path loss and calculation } \\
\text { of radius cell on LTE? }\end{array}$ \\
\hline 5. & $\begin{array}{l}\text { Evaluate the performance } \\
\text { of } 3 G \text { and } 4 G-L T E \\
\text { networks }\end{array}$ & $\begin{array}{l}\text { - Describe } 4 \text { of parameters used in analyzing LTE network } \\
\text { performance! }\end{array}$ \\
\hline 6. & $\begin{array}{l}\text { Understand how to } \\
\text { optimize } 3 G \text { and } 4 G-L T E\end{array}$ & - Describe the scope of RF Planning and RF Optimization \\
\hline
\end{tabular}


networks

Then the evaluation results can be seen in Table 4.

TABLE 4. Baseline, target, and learning outcomes by CTL method

\begin{tabular}{|c|c|c|c|}
\hline Parameter & Baseline & Target & Result \\
\hline Average mark & 63,78 & 75,00 & 78,91 \\
\hline $\begin{array}{l}\text { Conducting research } \\
\text { activities and writing } \\
\text { research reports }\end{array}$ & Not available & $\begin{array}{l}\text { Available, carried out in } \\
\text { groups }\end{array}$ & $\begin{array}{l}3 \text { research reports on } \\
\text { telecommunication } \\
\text { network design }\end{array}$ \\
\hline
\end{tabular}

The baseline used was the learning outcomes of the same course a year earlier. The use of average values considered sufficient to prove the difference in the use of this method with the previous conventional method with the reason that the class profile is relatively similar seen from the number and ability of students who follow this course. In the previous year there were 7 students and on the implementation now there are 9 students and both are students of the 7 th semester when taking this course.

Assessment is divided into three components, Mid exam with a weight of $15 \%$, Final Exam with a weight of $15 \%$, and design tasks with weight of $70 \%$. The task component has the largest share because the main focus in this lesson is the direct experience in learning and related to the application of science to reality.

Design tasks are carried out in groups using problem based learning approach (PBL). Because the design of the time is prepared for 3 to 4 groups, the participants are divided into three groups with three members each (the total number of participants is 9 students). This task is the largest component of the assessment $(70 \%)$ and is done in groups, whereas the final score is the individual value, it is necessary to evaluate individual performance in addition to group outcomes or performance.

Assessment of individual performance is done by looking at the activity of each individual when there are activities of presentation, discussion, and question and answer. Especially when there are question and answer activities, students who perform the task well will be able to answer correctly and coherently. Conversely, students who do less than optimal task then cannot answer correctly and systematically. So from a $70 \%$ portion of the design score, it is divided into $60 \%$ report and presentation value and $10 \%$ liveliness value in discussion.

\section{Student Feedback}

Based on the questionnaire on all students who attend this lecture, there are 9 students. All students stated that they considered this method of learning better than the usual method and made them more understanding of the material.

The impression that students get from this learning model, among others, they feel more excited, challenged, and full of cooperation. This is because from the beginning they have a clear problem / project and in accordance with reality in the field, and they work on the problem in small groups. Another benefit they gain is the direct experience of making research proposals, conducting research, and making research reports. They are very happy because they are more ready to do thesis.

\section{Lesson Learning}

Given the purpose of this method is direct learning based on reality and meaningful things, and the cooperation between participants, then this method is appropriate for the class with participants between 9 to 15 students. Where they will be divided into 3 up to 5 groups and each group has a maximum of 3 students.

The division of the value portion is more dominant in task activity, solving a particular problem or project. So the proposed portion is $60 \%$ to $70 \%$ for the assignment and $30 \%$ to $40 \%$ for the written exam (Midterm Exam and Final Exam).

The use of this method should be supported with sufficient reference books, because students are required to be more independent in finding information. Lecturers can distribute reference books to students or provide titles of reference books that can be easily accessed by students. Some of the 
recommended book titles for this course are Wireless ICT Network, Basic and Design [12] and Handbook 4G LTE.

Lecturers and students must spend more time outside the class hours to do the work and discuss. It should be prepared assistant courses, to assist lecturers in assisting students to work on problems or projects. The room used should have good facilities for discussion in small groups and carry out presentations.

The use of CBT method with PBL approach in Telecommunication Network Design and Optimization course can continue to be run considering the supporting elements that exist, such as: the availability of design and computer software is sufficient, the availability of handsets and software for data retrieval and network performance optimization, and the number of students who follow this course from 10 to 15 people. The reference book that has been purchased becomes the property of the Department of Electrical Engineering, so it can be reused in the next school year.

\section{CONCLUSION}

Eight components of the Contextual Teaching and Learning method (making meaningful connections, doing meaningful deeds, doing self-directed learning, working together, thinking critically and creatively, helping individuals to grow and develop, achieving high standards, and using authentic judgment) have been successfully applied to the Telecommunication Network Design and Optimization Course using Problem Based Learning (PBL) approach. PBL is primarily developed to help students develop thinking skills, problem solving and intellectual skills, learn various roles of adults through their involvement in reallife experiences or simulations; and become an autonomous and independent learner. The results can improve the achievement of competencies and provide direct experience to students to conduct research. This is evidenced by the increase of the average value from 63.78 to 78.91 and the availability of three research reports.

\section{ACKNOWLEDGMENT}

The author expresses gratitude to the Academic Development Board (BPA) of the Islamic University of Indonesia) for the teaching grant that has been given to the author.

\section{REFERENCES}

1. W. Sanjaya, Strategi Pembelajaran Berorientasi Standar Proses Pendidikan (Kencana Prenada Media, Jakarta, 2006).

2. R. Budiharti, Pembelajaran Fisika Dengan Pendekatan CTL (Contextual Teaching and Learning) Melalui Metode Demonstrasi, National Seminar on Biological Education of FKIP UNS 2010

3. H. Sabil, Edumatica, 1, 1, 2011.

4. A. Fortasoni, "Efektifitas Pembelajaran KKPI Pada Pokok Bahasan Mengoperasikan Operasi Sistem Graphics Dengan Menggunakan Model Pembelajaran Kooperatif Peta Konsep dan Model Pembelajaran CTL (Contextual Teaching Learning) Kelas X Di SMK Negeri 1 Singosari Malang", Bachelor, thesis, Malang State University, 2010.

5. E. B. Jonshon, Contextual Teaching \& Learning What It Is and Why It's Here To Stay (Corwin Press, California, 2002).

6. Nurhadi, Pendekatan Kontekstual (Dirjen Dikdasmen, Jakarta, 2002).

7. S. Adi, Audio Visual Sebagai Media Belajar (Gerbang, Jakarta, 2002).

8. A. Novia, "Studi Komparasi Pendekatan Contextual Teaching And Learning (CTL) Melalui Metode Eksperimen Laboratorium Dan Pemberian Tugas Terhadap Prestasi Belajar Siswa Pada Materi Pokok Reaksi Kimia Kelas VII Semester Genap SMP Negeri 1 Jaten Tahun Pelajaran 2009/2010" Bachelor, thesis, Sebelas Maret University, 2011.

9. S. Ariyanti, "Studi Perencanaan Jaringan Long Term Evolution Area Jabotobek Studi Kasus PT. Telkomsel" Buletin Pos dan Telekomunikasi, Puslitbang SDPPI No. 4 / Vol.12 / December 2014.

10. F. R. J. Purba, "Analisis Perancangan Jaringan Long Term Evolution (LTE) di Wilayah Kota Banda Aceh Dengan Fractional Frequency Reuse Sebagai Manajemen Interferensi”, Bachelor, thesis, Telkom University, 2014. 
11. W. H. Pratama, "Analisis Perencanaan Jaringan Long Term Evolution (LTE) Menggunakan Metode Reuse 1, Fractional Frequency Reuse, dan Soft Frequency Reuse Studi Kasus Kota Bandung", Bachelor, thesis, Telkom University, 2014.

12. Firdaus, M. Fahri, and E. Nuraini, Dasar dan Perancangan Wireless ICT Networks (3G 4G (LTE) 4G (WIMAX) - 5G - Satelit, (UII Press, Yogyakarta, 2015). 